Arab Univ. J. Agric. Sci., Ain Shams Univ., Cairo, Egypt 28(1), 315-327, 2020

Website: http://ajs.journals.ekb.eq

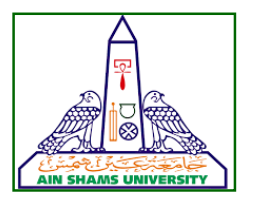

\title{
EFFECT OF CERTAIN PSEUDOMONAS FLUORESCENS ISOLATES ON THE INFECTION OF ROOT-KNOT NEMATODE, MELOIDOGYNE INCOGNITA IN TOMATO AND EGGPLANT AND THE PLANT GROWTH
}

\author{
Nora R.A. Sahel ${ }^{1^{*}}$, Mahgoob ${ }^{2}$ A.E.A., Entesar H. Taha², Wafaa M.A. \\ El-Nagdi ${ }^{1}$, Youssef ${ }^{1}$ M.M.A. and Mona M.S. Zayed ${ }^{3}$
}

1- Plant Pathology Dept., Nematology Lab., National Research Center, Dokki, Giza, Egypt

2- Plant Protection Dept., Fac. of Agric. Ain Shams Univ., P.O. Box 68, Hadayek Shoubra 11241, Cairo, Egypt

3- Microbiology Dept., Fac. of Agric., Ain Shams Univ., P.O. Box 68, Hadayek Shoubra 11241, Cairo, Egypt

*Corresponding author: norasaleh7841@yahoo.com

Received 30 January, 2020

Accepted 19 March, 2020

\section{ABSTRACT}

Under screen house conditions, two experiments were carried out to evaluate certain bacterium, Pseudomonas fluorescens isolates regarding reproductive potential of root-knot nematode, Meloidogyne incognita, infecting tomato or eggplant. Results on tomato revealed that, on the basis of average total percentages nematode reduction, the over topped results were gained with $P$. fluorescens $\left(\mathrm{Pf}_{2}\right)$ which recorded the highest significant $(P \leq 0.05)$ average nematode reduction $(61.3 \%)$ and higher percentage reduction of females $(77 \%)$ per plant. The second rank was obtained by $\mathrm{Pf}_{3}$ which reduced all nematode numbers as an average of $56.9 \%$. On the basis of average total percentages plant growth and weight of fruit increases, four bacterial treatments can be ranked in a descending order as follows: $\mathrm{Pf} 9>\mathrm{Pf}_{4}>\mathrm{Pf}_{1}$ and $\mathrm{Pf}_{7}$, as they achieved the highest average total percentages increases of $96.0,47.3,38.2$ and $29.8 \%$, respectively compared to other treatments and untreated check. Regarding to eggplant, the over topped results observed was achieved by $P$. fluorescens $\left(\mathrm{Pf}_{10}\right)$ which recorded the highest average total nematode reduction $(66.2 \%)$ with higher reduction of $\left(\mathrm{J}_{2} \mathrm{~S}\right)$ in roots (89.9\%) per plant and in soil $(78.8 \%)$ per pot. The second rank was obtained by $\mathrm{Pf}_{9}$ and $\mathrm{Pf}_{2}$ where they reduced all nematode numbers as averages of $55.9 \%$ and $54.9 \%$, respectively. Also Pseudomonas isolates enhanced the plant growth of eggplant, averages were found in a descending order as follows: $\mathrm{Pf}_{1}(20.0 \%), \mathrm{Pf}_{9}(18.7 \%)$ and $\mathrm{Pf}_{10}(18.3 \%)$. It is worthy to note that the most distinct growth criteria was fresh weight of roots as it achieved higher percentage increase $(58.1 \%)$ by using $\mathrm{Pf}_{9}$ followed by $\mathrm{Pf}_{1}$ as it caused $40.6 \%$ increase compared to untreated check. The highest average percentage of fresh weight of shoot were recorded for $\mathrm{Pf}_{10}(26.4 \%)$ and Pf8 (22.1\%). Whereas for dry weight $\mathrm{Pf}_{3}(29.8 \%)$ and $\mathrm{Pf}_{2}(19.1 \%)$. In conclusion, the tested biocontrol agent was efficient in controlling the root-knot nematode on tested plants.

Keywords: Pseudomonas fluorescens isolates, Tomato, Eggplant, Meloidogyne incognita.

\section{INTRODUCTION}

Root-knot nematodes belonging to the genus of Meloidogyne known as an endoparasite cause rootknot symptoms and serious plant damage (Trudgill and Blok 2001). Plant parasitic nematodes reducing production by $12-20 \%$ worldwide were studied widely (Oka et al 2000), moreover losses can reach 30-60\% (Talavera et al 2012) in protected cultivation. Efforts were directed to use the biological control as environmental friendly management of root knot nematodes (Timper 2011). Plant growth-promoting rhizobacteria (PGPR) can protect plants against nematodes (El-Hadad et al 2010 and 
Oliveira et al 2007). Approximately, $7-10 \%$ of all rhizobacteria act as antagonistic agents against nematodes by more than mode of action, including competition, antibiosis and induced resistance (Burkett-Cadena et al 2008). Under pot experiments, several Pseudomonas species were effective in managing root- knot nematode (Siddiqui et al 2009, Singh and Siddiqui 2010). Kavitha et al (2011) mentioned that soil application by the native isolates Pft 20 ( $P$. fluorescens) at $2.5 \mathrm{~kg} / \mathrm{ha}$ significantly reduced the infestation of root-knot nematode, $M$. incognita in the treated tomato both in soil and roots as indicated by the reduction in number of the studied nematode criteria and increasing in the plant growth. Mokbel and Alharbi (2014) evaluated the efficacy of certain bacterial genera against $M$. javanica on eggplant as egg-hatch inhibition and reduction in $2^{\text {nd }}$ stage juveniles percentages ranged from 50.5-90.3\% were obtained by using Bacillus subtilis, $B$. thuringiensis, $P$. fluorescens and Serratia marcescens. Also, they observed that $56.5-86.8 \%$ reductions in the number of galls, egg-masses/root system, and number of $\mathrm{J}_{2} \mathrm{~s}$. Subsequently, 50.9$73.7 \%$ increases in the root and shoot dry weights of eggplant occurred. The information about the efficacy of biocontrol agents in controlling root-knot nematodes needs more expanded researches. Therefore, this research was designed to evaluate certain Pseudomonas fluorescens isolates for their nematicidal efficacy on root-knot nematode, $M$. incognita infecting tomato and eggplant and subsequently on their plant growth.

\section{MATERIALS AND METHODS}

\section{Preparation of root-knot nematode pure cul- ture and inoculum}

The tested species of root-knot nematode was Meloidogyne incognita, identified from nematode adult female according to the morphological characteristics of the female perineal pattern (Taylor and Sasser 1978). Pure culture of $M$. incognita was reared on eggplant $\mathrm{cv}$. Ice under screen house conditions at $30 \pm 5^{\circ} \mathrm{C}$ by using a single egg-mass of this nematode. Newly hatched second stage juveniles $\left(\mathrm{J}_{2} \mathrm{~s}\right)$ were used as inoculum.

\section{Bacterial isolates}

\subsection{Source of Pseudomonas fluorescens} isolates

Twelve soil samples ( $200 \mathrm{~g}$ soil) were taken from the rhizospheres of eggplant and tomato plants cultivated in El-Beheira and Monoufyia Governorates, Egypt.In addition, 3 soil samples of pepper plant only were collected from El-Beheira Governorate. All samples were free from root-knot nematode infestation; the samples were transferred to the laboratory of PPD-NRC for isolation and identification of Pseudomonas fluorescens.

\subsection{Isolation and identification of $\boldsymbol{P}$. fluorescens}

For isolation of $P$. fluorescens, the total plate counts technique and dilution method were carried out according to (Ghini et al 2007). Each collective sample (Ten gram) was transferred into $250 \mathrm{ml}$ conical flask containing $90-\mathrm{ml}$ of sterile distilled water to prepare serial dilutions ranging from $10^{-1}$ to $10^{-7}$. One $\mathrm{ml}$ of each sample dilution was pipetted onto the surface of sterile Petri-dish (9 cm diam.) containing KB (King's medium B)[Peptone 20.0g; Glycrol $15.0 \mathrm{ml} ; \mathrm{K}_{2} \mathrm{HPO}_{4}$ (anhydrous) $1.5 \mathrm{~g} ; \mathrm{MgSO}_{4} \times 7 \mathrm{H}_{2} \mathrm{O}$; Agar $15.0 \mathrm{~g}$ in 1.0 liter of distilled water at $\mathrm{pH} 7.2 \pm$ $0.2]$. The soil suspension was spread on the surface of medium using glass rod (L-shape). The inoculated plates was incubated at $28^{\circ} \mathrm{C}$ for $48 \mathrm{~h}$. The growing bacterial colonies were examined with UV light for detection fluorescent pigment production. Subsequently, the bacterial colonies, which showed fluorescent pigment, were picked soon on slant of nutrient glucose $2 \%$ agar medium (NGA) [Beef extract 3.0g ; Peptone 5.0g; Glucose 20.0g; Agar 15.0g in 1.0 liter of distilled water at $\mathrm{pH} 7.2 \pm 0.2$ ].

Nine $P$. fluorescens isolates were isolated from the collected rhizosphere samples (Table 1 and 2). The isolates were identified according to cultural characters on NGA medium and LOPAT test (Levan production, Oxidase test, pectolytic enzymes, arginine dihydrolase and hyper sensitivity reaction) using standard bacteriological methods (Schaad 1980, Lelliot and Stead 1987 and Goszczynska et al 2000).

Justification of bacterial inoculums for each isolate reached $10^{7}-10^{9}$ colony forming unit $(\mathrm{CFU}) / \mathrm{ml}$ by turbidity method (Baid et al 2000) and was applied as mixture of bacterial cells and cultural filtrate. 

nematode, Meloidogyne incognita in tomato and eggplant and the plant growth

Table 1. Location, source and name of the tested bacterial isolates

\begin{tabular}{|c|c|c|c|}
\hline Governorate & Source plant & No. of samples & Bacterial isolate \\
\hline \multirow{3}{*}{ El-Beheira } & Egg plant & 3 & $\mathrm{Pf}_{1}$ \\
& & & $\mathrm{Pf}_{2}$ \\
& Pepper & 3 & $\mathrm{Pf}_{3}$ \\
& & & $\mathrm{Pf}_{4}$ \\
& Tomato & 3 & $\mathrm{Pf}_{5}$ \\
& & & $\mathrm{Pf}_{7}$ \\
\hline \multirow{2}{*}{ El-Monoufyia } & Egg plant & 3 & $\mathrm{Pf}_{8}$ \\
& Tomato & 3 & $\mathrm{Pf}_{9}$ \\
\hline
\end{tabular}

Table 2. Identification of some green fluorescent Pseudomonas by the LOPAT scheme

\begin{tabular}{|c|c|c|c|c|c|}
\hline \multirow{2}{*}{$\begin{array}{c}\text { P. flourescens } \\
\text { Isolates } \\
\text { (Ivb) }\end{array}$} & \multicolumn{5}{|c|}{ LOPAT Test } \\
\cline { 2 - 5 } & $\begin{array}{c}\text { Levan } \\
\text { Production }\end{array}$ & $\begin{array}{c}\text { Oxidase } \\
\text { Test }\end{array}$ & $\begin{array}{c}\text { Potato Soft } \\
\text { Rot }\end{array}$ & $\begin{array}{c}\text { Arginin } \\
\text { Dihydrolase }\end{array}$ & $\begin{array}{c}\text { Tobacco Hyper } \\
\text { Sensitive } \\
\text { Reaction }\end{array}$ \\
\hline Pf1 & - & + & + & + & - \\
Pf2 & - & + & + & + & - \\
Pf3 & - & + & + & + & - \\
Pf4 & - & + & + & + & - \\
Pf5 & - & + & + & + & - \\
Pf6 & - & + & + & + & - \\
Pf7 & - & + & + & + & - \\
Pf8 & - & + & + & + & - \\
Pf9 & - & + & + & + & - \\
\hline
\end{tabular}

\section{Source of standard $P$. fluorescens isolate}

A standard $P$. fluorescens $\mathrm{Pf}_{10}$ (NRC isolate) was obtained from (PPD-NRC). The inoculum of this isolate was prepared as mentioned previously.

\section{Source of Micronema ${ }^{\circledR}$}

The commercial bio-nematicide, Micronema ${ }^{\circledR}$ (mixture of certain beneficial bacteria) was obtained from the Agricultural Research Center (Giza, Egypt) and used with the recommended dose.
The standard $P$. fluorescens $\mathrm{Pf}_{10}$ (NRC isolate) and Micronema ${ }^{\circledR}$ were used for comparison.

\section{Tested plants}

Seeds of tomato (Lycopersicum esculentum) cv. Castle Rock and eggplant (Solanum melongena) cv. Ice. were obtained from Agricultural Research Center, Giza, Egypt. Seeds were sown in a nursery for germination and maintained till the seedling reached one-month- old. 


\section{In vivo evaluation of the $P$. fluorescens isolates against $M$. incognita}

Under screen house conditions, two experiments were conducted in PPD-NRC, in order to differentiate the potential of $P$. fluorescens isolates on $M$. incognita infecting tomato and eggplant.

\subsection{Tomato experiment}

One-month-old of tomato seedlings were transplanted into $20-\mathrm{cm}$ diameter plastic pots (one seedling/pot) containing $2 \mathrm{~kg}$ of solarized sandy loamy soil (1:1) in August 2-2015. A week later, second stage juveniles of $M$. incognita at the rate of 1000 individuals per pot were inoculated around the vicinity of each seedling. At the same time, the inoculation of each tested $P$. fluorescens isolates, inoculated to each seedling with a rate of $30 \mathrm{ml} / \mathrm{pot}\left(10^{-7}\right.$. $10^{-9}$ colony forming unit (CFU) $\left./ \mathrm{ml}\right)$. The commercial product, Micronema ${ }^{\circledR}$ was used at the recommended rate $(0.5 \mathrm{ml} / \mathrm{pot})$ as comparison. Nematodes only in 30-ml distilled water were used as untreated check.

\subsection{Eggplant experiment}

The same procedures in tomato were carried out except that; eggplant seedlings were transplanted in May 15, 2016. A week later, each pot was inoculated with 500 newly hatched juveniles $\left(\mathrm{J}_{2} \mathrm{~S}\right)$ of $M$. incognita. Simultaneously, seedlings of eggplant were treated with 9 isolates of $P$. fluorescens. Also the standard $P$. fluorescens $\mathrm{Pf}_{10}$ (NRC isolate) isolate was used as comparison. In both experiments, pots were arranged in a completely randomized design with 6 replicates for each treatment on a bench and maintained, plants were irrigated as needed.

\section{Determination of $M$. incognita and plant growth parameters}

\subsection{M. incognita parameters}

Plants of tomato and eggplant were harvested after three months from inoculation with nematodes and carefully uprooted. Roots were washed thoroughly with running tap water to get rid of soil aggregation and debris. Then, roots were cut into two halves. In one half, acid fuchsin in cold lacto-phenol was used to stain and store roots for not less than $24 \mathrm{hr}$. After that, stained roots were put in water and cut into pieces to enable counting of galls, females, and egg masses. Incubation method described by
(Young 1954) was used for the remaining half of roots by incubating in tap water for obtaining $\mathrm{J}_{2} \mathrm{~S}$ from egg masses. The number of $\left(\mathrm{J}_{2} \mathrm{~S}\right)$ in the soil was extracted using a sieving and decanting technique (Barker 1985) and counted. Numbers of nematodes $\left(\mathrm{J}_{2} \mathrm{~S}\right)$ were counted under a light microscope. Average total percentages nematode reduction was calculated to compare among treatments. Rate of nematode reproduction $(\mathrm{Rr})$ was calculated by dividing final nematode population (Pf) by the initial population $(\mathrm{Pi})$.

\subsection{Plant growth parameters}

Plant growth criteria including shoot length $(\mathrm{cm})$, fresh and dry shoot weights $(\mathrm{g})$ and fresh root weight $(\mathrm{g})$ of tomato and eggplant were recorded. Also, weight of fruits $(\mathrm{g})$ was registered.

\section{Statistical analysis}

Statistically data of the present experiment were subjected to analysis by (ANOVA) procedures. Comparison was made for treatment at $5 \%$ probability by Duncan's Multiple Range Test as reported by Snedecor and Cochran (1989). This was carried out by Computerized Statistical Package (COSTAT) User Manual Version 3.03, Barkley Co.

\section{RESULTS}

\section{1- Influence of certain $P$. fluorescens isolates on root-knot nematode, Meloidogyne incognita infecting tomato}

Under screen house conditions, nine bacterial isolates were tested, for their nematicidal efficacy to control $M$. incognita infecting tomato as indicated by number of nematode juveniles $\left(\mathrm{J}_{2} \mathrm{~S}\right)$ in soil and roots, females, galls and egg masses compared to a commercial product namely, Micronema ${ }^{\circledR}$ and untreated check. Table (3) illustrates mean numbers of treatments and untreated check. In general, all bacterial isolates had suppressive effect on $M$. incognita, when number of the studied nematode reproductive criteria and galls were significantly $(P \leq 0.05)$ reduced at various degrees on the basis of average total percentages nematode reduction. The over topped results gained were achieved by $P$. fluorescens $\left(\mathrm{Pf}_{2}\right)$ which recorded the highest average total percentages nematode reduction $(61.3 \%)$ and high percentage reduction of females $(77 \%)$ per plant. The second rank was obtained by $\mathrm{Pf}_{3}$, where it reduced all reproductive nematode numbers as an 

nematode, Meloidogyne incognita in tomato and eggplant and the plant growth

average total percentages reduction (56.9\%) with the highest percentage reduction of females $(84.7 \%$.) and $78.3 \%$ for number of second stage juveniles in roots. This was followed by Micronema ${ }^{\circledR}$ which caused $56 \%$ and was as effective as some treatments in reducing number of females by $58.1 \%$. However, the percentages reduction of galls behaved an independent pattern, as they recorded the highest reduction (48.1\%) caused by $\mathrm{Pf}_{1}$ followed by $\mathrm{Pf}_{4}(43.8 \%)$. On the other hand, control treatment (untreated infected plants) showed the highest numbers and galls of root knot nematode. Obviously, the isolates of $\mathrm{Pf}_{2}$ and $\mathrm{Pf}_{3}$ recorded the lowest reproduction rates (2.9 and 2.4), respectively followed by Micronema ${ }^{\circledR}$. The reproduction rate of the other isolates ranged from 3.7-4.8.

2- Effect of certain $P$. fluorescens isolates on tomato growth and yield infected by Meloidogyne incognita

Concerning tomato growth, a significant $(P \leq 0.05)$ augmentation of shoot length, fresh and dry weights, root fresh weight and weight of fruits as influenced by the tested isolates of $P$. fluorescens are illustrated in Table (4). On the basis of average total percentages of plant growth, $\mathrm{Pf}_{9}$ isolate was superior in increasing shoot length, shoot and root fresh weights as four bacterial treatments can be ranked in a descending order as follows: $\mathrm{Pf}_{9}$ $>\mathrm{Pf}_{4}>\mathrm{Pf}_{1}$ and $\mathrm{Pf}_{7}$ achieved the highest percentages increase $(96.0,47.3,38.2$ and $29.8 \%$ ), respectively compared to other treatments and untreated check. As for weight of fruits, $\mathrm{Pf}_{9}$ achieved the highest percentage increase (194.6\%) followed by $\mathrm{Pf}_{2}(95.7 \%)$ and $\mathrm{Pf}_{4}(80.4 \%)$, whereas Micronema ${ }^{\circledR}$ caused $66.3 \%$ only.

\section{3- Influence of certain P. fluorescens isolates on root-knot-nematode, Meloidogyne incognita infecting eggplant}

Also, the nine bacterial isolates in addition the standard isolate $\left(\mathrm{Pf}_{10}\right)$ were tested, for their efficacy on $M$. incognita infecting eggplant. Averages number of nematode juveniles in soil and roots, females, egg masses per root system as well as number of galls were used as indicators. In general, on the basis of these indicators, data in Table (5), indicated that all tested bacterial isolates had significantly $(P \leq 0.05)$ suppressed $M$. incognita $\left(\mathrm{J}_{2} \mathrm{~S}\right)$ in the above mentioned nematode criteria compared to the untreated check. The over topped results gained was achieved by $P$. fluorescens $\left(\mathrm{Pf}_{10}\right)$ which recorded the highest average total nematode reduction $(66.2 \%)$ with higher reduction of $\left(\mathrm{J}_{2} \mathrm{~S}\right)$ in roots $(89.9 \%)$ and in soil $(78.8 \%)$ per plant. The second rank was obtained by $\mathrm{Pf}_{9}$ and $\mathrm{Pf}_{2}$ as they reduced all nematode numbers with averages $55.9 \%$ and $54.9 \%$, respectively. The highest reductions of $\mathrm{J}_{2} \mathrm{~S}$ in soil $(77.1 \%)$ and female $(72.4 \%)$ in root were recorded by $\mathrm{Pf}_{1}$. However, the percentages reduction of galls behaved an independent pattern, as they were reduced by $71.9 \%$ caused by $\mathrm{Pf}_{6}$ followed by $\mathrm{Pf}_{9}(69.2 \%)$. On the other hand, the lowest reproduction rates $(\mathrm{Rr})$ were recorded by the isolates $\mathrm{Pf}_{10}$ (3.4), $\mathrm{Pf}_{2}$ (5.8), $\mathrm{Pf}_{9}$ (6.97) and $\mathrm{Pf}_{1}$ (9.1). In contrast, control treatment (untreated infected plants) registered the highest numbers in all nematode parameters.

\section{4- Effect of certain Pseudomonas fluorescens isolates on eggplant growth parameters infected by Meloidogyne incognita}

Concerning eggplant growth as influenced by the tested bacterial isolates, mean numbers of shoot length, fresh and dry weights and root fresh weight and untreated check are illustrated in Table (6). Results indicated that, three treatments significantly $(P \leq 0.05)$ promoted plant growth criteria than the other treatments and un-infected untreated plants as follows: averages total percentages plant growth increase of $\mathrm{Pf}_{1}(20.0 \%), \mathrm{Pf}_{9}(18.7 \%)$ and $\mathrm{Pf}_{10}$ $(18.3 \%)$ were found in a descending order. It is worthy to note that the most distinct growth criteria was fresh weight of roots, as it achieved higher percentage increase $(58.1 \%)$ by using $\mathrm{Pf}_{9}$ followed by $\mathrm{Pf}_{1}$ caused increase $40.6 \%$ compared to untreated check. The highest average percentages increase recorded for fresh weight of shoot were achieved by $\mathrm{Pf}_{10}(26.4 \%)$ and $\mathrm{Pf}_{8}(22.1 \%)$, while for dry weight, the most effective isolates were $\mathrm{Pf}_{3}(29.8 \%)$ and $\mathrm{Pf}_{2}$ (19.1\%). 


\begin{tabular}{|c|c|c|c|c|}
\hline \multirow{13}{*}{ 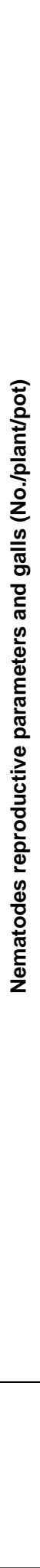 } & 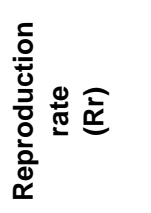 & 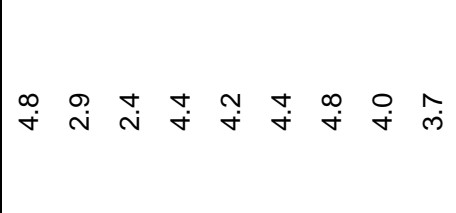 & $\begin{array}{l}0 \\
\dot{m}\end{array}$ & $\begin{array}{l}9 \\
0\end{array}$ \\
\hline & 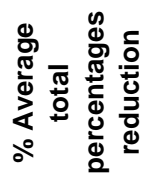 & 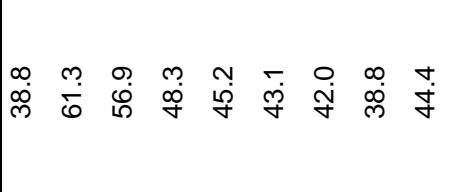 & $\begin{array}{l}0 \\
0 \\
i \\
i n\end{array}$ & 0 \\
\hline & 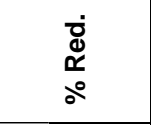 & 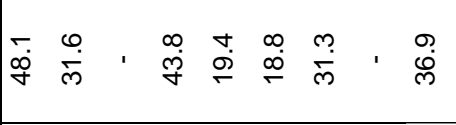 & $\stackrel{\ddot{\sim}}{\sim}$ & 0 \\
\hline & $\frac{\infty}{\bar{\sigma}}$ & 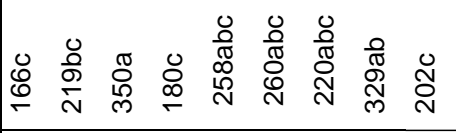 & 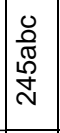 & 这 \\
\hline & $\begin{array}{l}\dot{0} \\
\stackrel{0}{\pi} \\
\stackrel{0}{\circ}\end{array}$ & 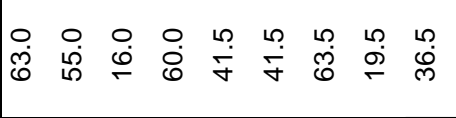 & 얼 & 0 \\
\hline & 总怘 & 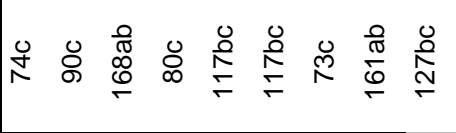 & $\ddot{\circ}$ & 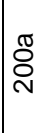 \\
\hline & $\therefore$ 욤 & 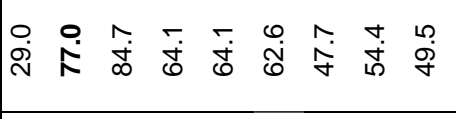 & $\bar{\infty}$ & 0 \\
\hline & 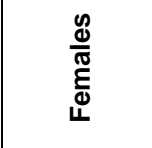 & 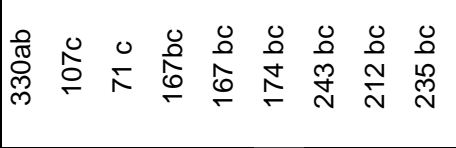 & 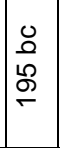 & 番 \\
\hline & 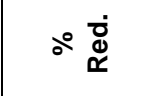 & 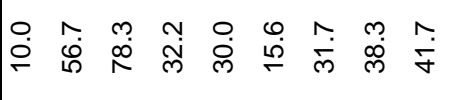 & $\begin{array}{l}\infty \\
i \\
i \\
\end{array}$ & 0 \\
\hline & $\stackrel{\substack{\infty \\
\stackrel{\infty}{0}}}{\stackrel{0}{\supset}}$ & 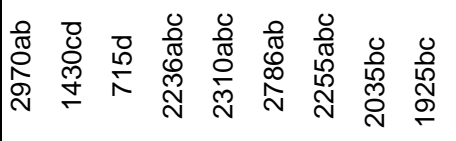 & 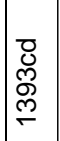 & 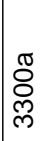 \\
\hline & $\therefore$ 远 & 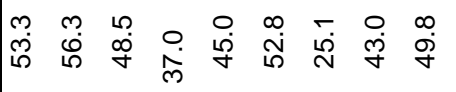 & $\begin{array}{l}0 \\
i \infty \\
i n\end{array}$ & 0 \\
\hline & 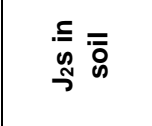 & 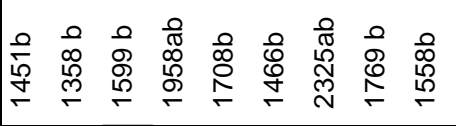 & 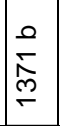 & $\begin{array}{l}\mathscr{\pi} \\
\frac{0}{m} \\
\text { m }\end{array}$ \\
\hline & 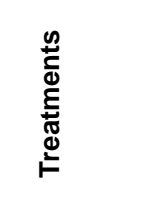 & 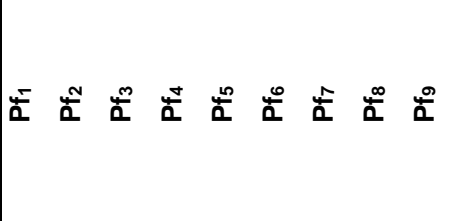 & 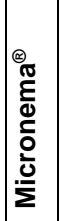 & 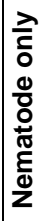 \\
\hline
\end{tabular}




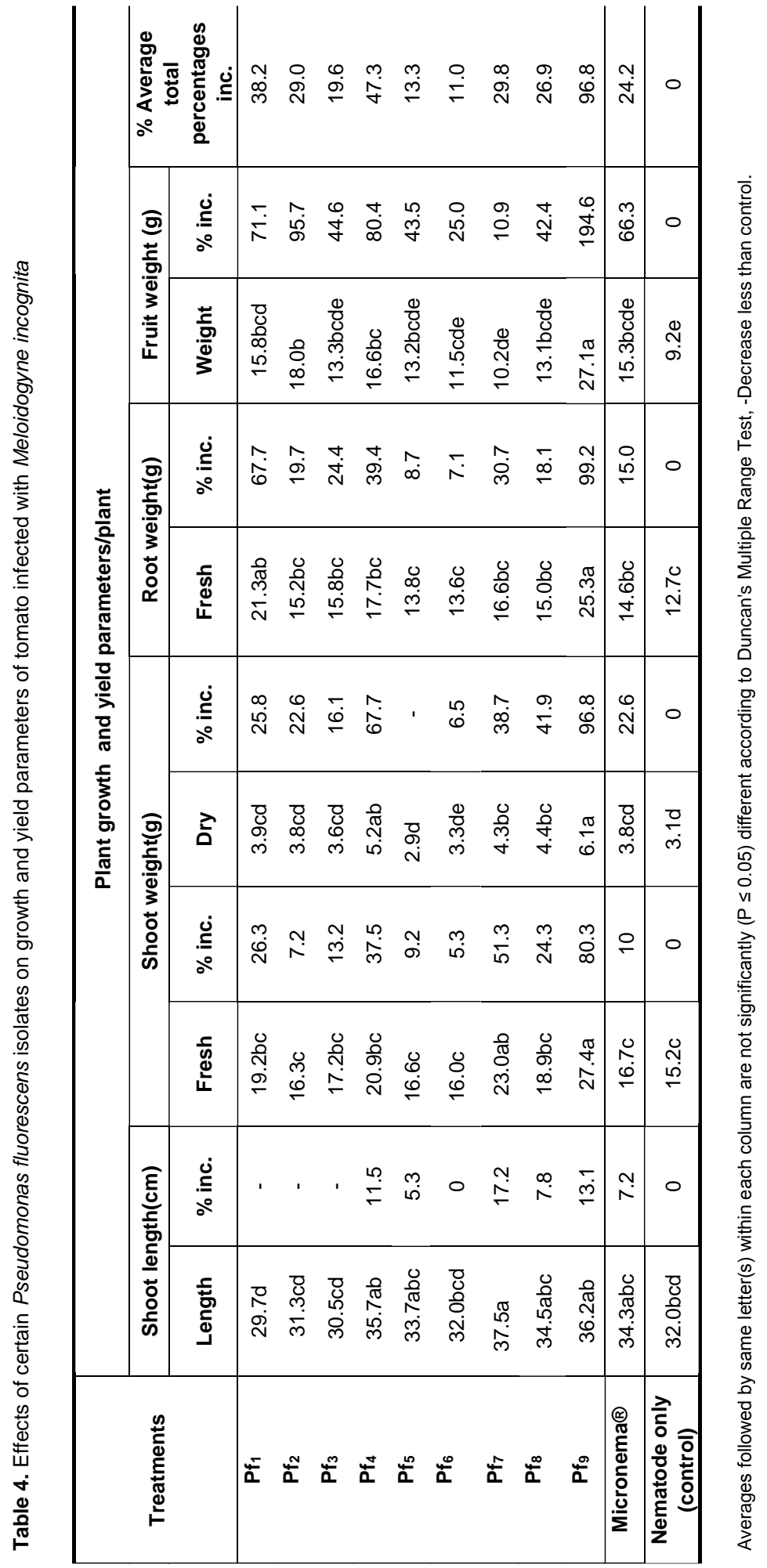




\begin{tabular}{|c|c|c|c|c|}
\hline & 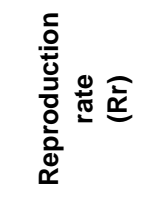 & 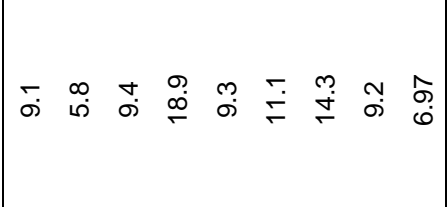 & 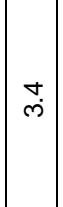 & 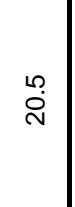 \\
\hline \multirow{11}{*}{ 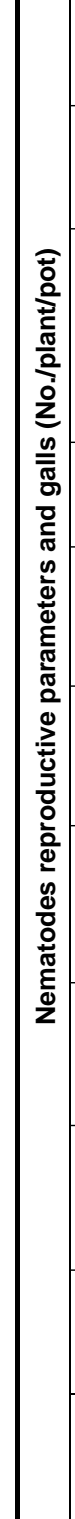 } & 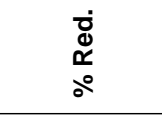 & 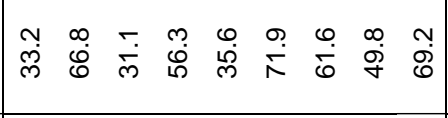 & \begin{tabular}{|l|}
0 \\
0 \\
0 \\
0
\end{tabular} & 0 \\
\hline & $\frac{\mathscr{m}}{\bar{E}}$ & 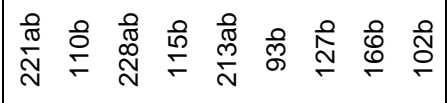 & $\frac{0}{0}$ & $\frac{\sigma}{p}$ \\
\hline & 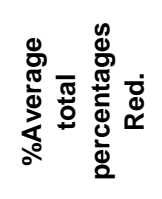 & 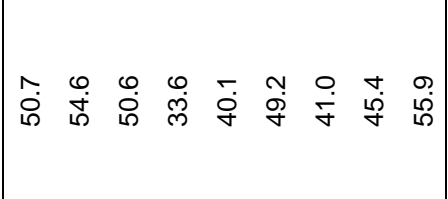 & $\mid \begin{array}{l}n \\
\dot{\theta} \\
0\end{array}$ & 0 \\
\hline & $\circ \underset{\varpi}{\varpi}$ & 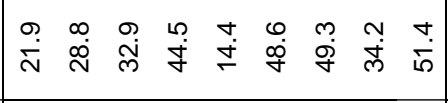 & $\hat{\stackrel{\rho}{\rho}}$ & 0 \\
\hline & 寓 & 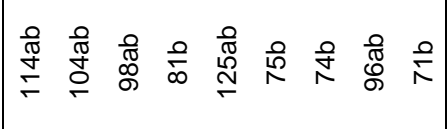 & \begin{tabular}{|l|} 
\\
$\infty$ \\
$\infty$
\end{tabular} & 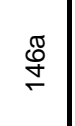 \\
\hline & 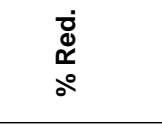 & 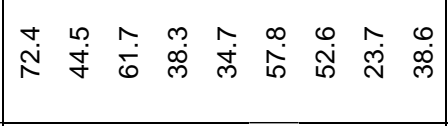 & 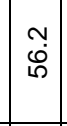 & 0 \\
\hline & $\begin{array}{l}\frac{\mathscr{g}}{\tilde{\Phi}} \\
\frac{\tilde{E}}{\mathscr{L}} \\
\text { L }\end{array}$ & 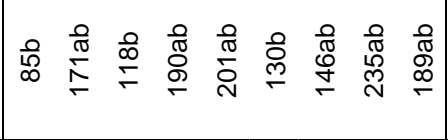 & 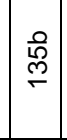 & 怘 \\
\hline & $\begin{array}{l}\dot{8} \\
\mathbb{0} \\
\stackrel{0}{0} \\
\circ\end{array}$ & 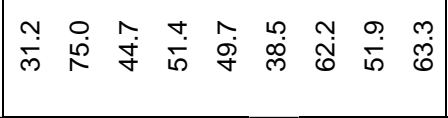 & $\begin{array}{l}\dot{Q} \\
\dot{\infty} \\
\infty\end{array}$ & 0 \\
\hline & $\begin{array}{l}\subseteq \stackrel{\infty}{0} \\
\stackrel{0}{\circ} \stackrel{0}{\circ}\end{array}$ & 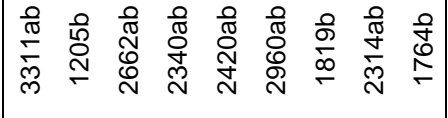 & 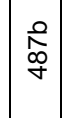 & 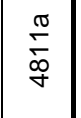 \\
\hline & $\begin{array}{l}\text { कृ } \\
\stackrel{0}{0} \\
\stackrel{0}{\circ}\end{array}$ & 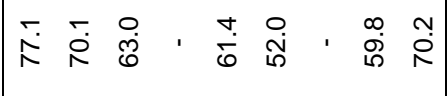 & 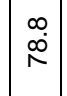 & $\circ$ \\
\hline & $\begin{array}{l}\subseteq \\
\stackrel{\infty}{s} \bar{i}\end{array}$ & 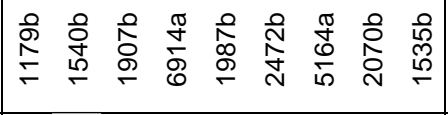 & 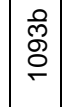 & $\frac{\pi}{0}$ \\
\hline & 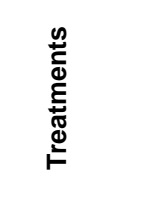 & 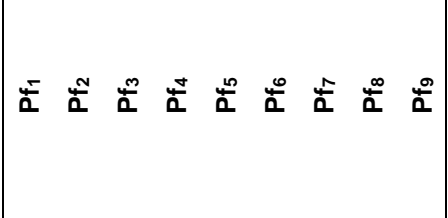 & 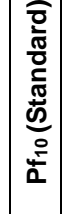 & 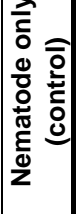 \\
\hline
\end{tabular}




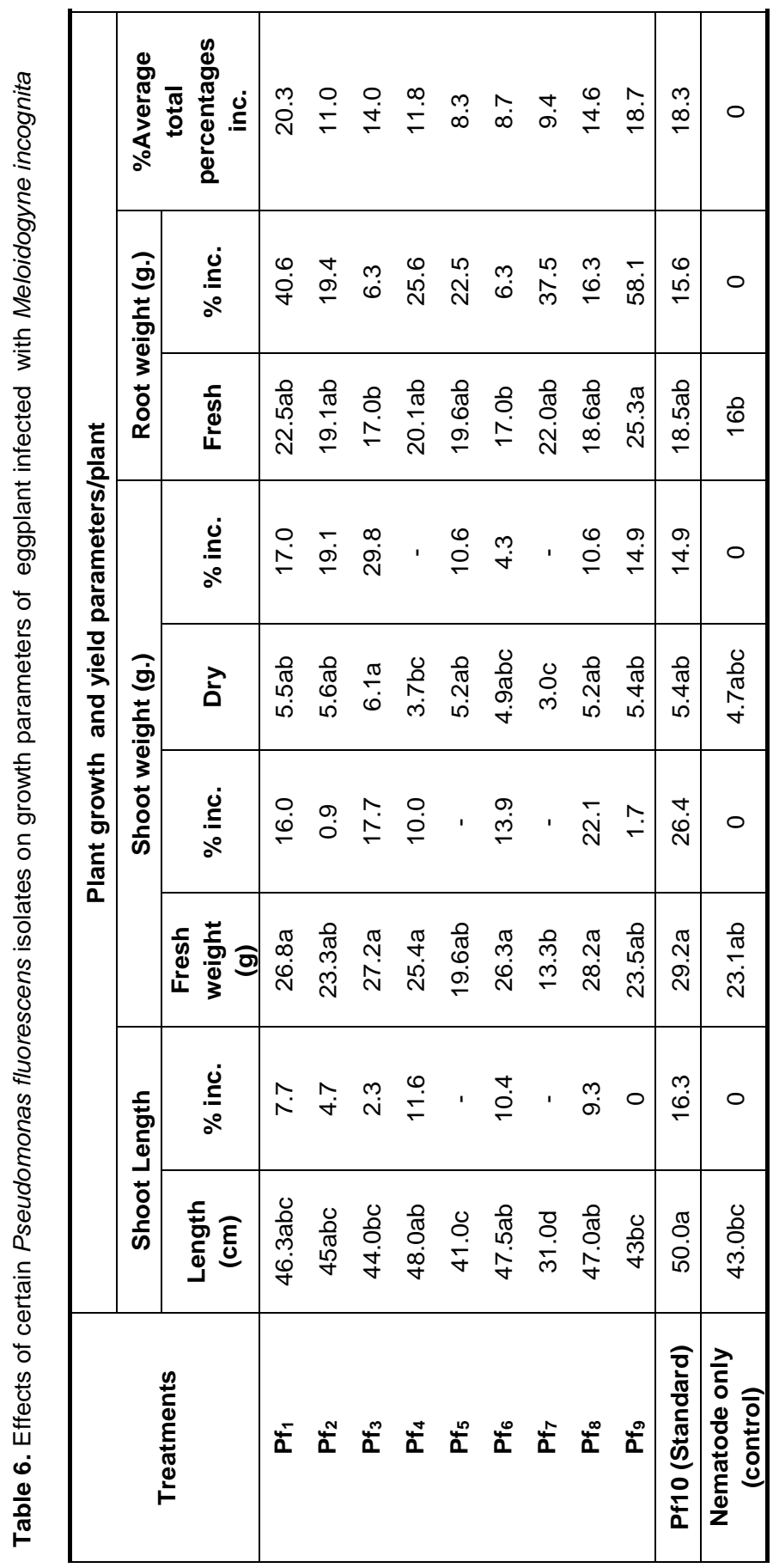




\section{DISCUSSION}

As a result of cellular metabolism, fluorescent pseudomonad isolates can produce exotoxic compounds and also can affect nematode juveniles as reported by Wescott and Kluepfel (1993) which conform to the present study regarding efficacy of certain $P$. fluoresens isolates for controlling $M$. incognita on tomato or eggplant. This effect may refer to the selective permeability changes of juvenile's cuticle and this effect is more pronounced with molting inside eggs. These results are similar to those obtained by Ashoub and Amara (2010). Plant growth promoting pseudomonads, antibiotic production, and competition with pathogens for essential nutrients such as iron and more, may act to induce direct antagonism against pathogens (Gamliel and Katan1993). The efficacy of Micronema ${ }^{\circledR}$ against $M$. incognita may refer to that it contain some beneficial bacterial isolates which are well known to suppress nematodes as follows: El- Hadad et al (2010) stated that the nematode numbers were significantly reduced particularly, 60 days after inoculation by nitrogen fixing bacterium, Azotobactersp. and the potassium solubilizing bacterium, Bacillus circulans. Zavaleta-Mejia and Van Gundy (1989) reported that Serratia marcescens reduced juveniles of $M$. incognita which may be due to volatile materials produced during its metabolic activity (Ali 1996 and El-Sherif et al 1999). Eklund (1970) showed that some Pseudomonads convert amino acids present in root exudates to ammonia suppressive to pathogens. Also, El-Nagdi and Youssef (2015) clarified that gall reduction reached $69.3 \%$ by Micronema ${ }^{\circledR}$ on sugar beet infected by $M$. incognita. The same percentages nematode gall reduction occurred when Micronema treated on date palm which may be due to that juveniles were unable to penetrate the host root as reported by Youssef et al (2014). The obtained present results conform with those reported by Stirling and Sharma (1990) and El-Nagar et al (1998) who showed that, Pasteuria penetrans reduced number of root-knot nematodes which led to decreased infectivity of the juveniles. In accordance, the product, agerin which contains Bacillus thuringiensis reduced the number of root knot nematode (Noweer and Hasabo 2005) by releasing toxins that suppressed synthesis of proteins and nucleic acids in nematode (Sebesta et al 1969).Coinciding with these results, Sohrabi et al (2018) reported that to- mato growth criteria infected by $M$. javanica was affected by four plant growth-promoting rhizobacteria (PGPR) and indicated that the PGPR significantly affected the reproductive factor of the nematode by $P$. fluorescens which was reduced from 112.15 to 24.94 and significantly improved the plant growth parameters. Also, El-Nagdi et al (2019) reported that $P$. fluorescens caused the highest percentage nematode reduction (89\%) of $M$. incognita on cowpea and caused average increase of $55.6 \%$ in the studied plant growth parameters which conform to the present study. Finally, the different effects of the tested bacterial isolates on $M$. incognita as affected by eggplant and tomato may be due to the differences in genetic composition and degree of host susceptibility against root-knot nematode between these plants

\section{REFERENCES}

Ali A.H. 1996. Biocontrol of reniform and root-knot nematodes by new bacterial isolates. Bull. Fac. Agric., Cairo Univ., Giza, Egypt, 47, 487-497.

Ashoub A.H. and Amara M.T. 2010. Biocontrol activity of some bacterial genera against rootknot nematode, Meloidogyne incognita. J. Am. Sci., 6(10), 321-328.

Baid R.M., Hodges N.A. and Denyer S.P. 2000. Handbook of Microbiolgy Quality Control: Pharmaceuticals and Medical Devices. London; UK, $280 \mathrm{p}$.

Barker K.R. 1985. Nematode Extraction and Bioassays. In: An Advanced Treatise on Meloidogyne, Vol. II: Methodology, Barker K.R., Carter and Sasser J.N. (Ed.). North Carolina State Univ. Graphics, USA. pp. 19-35.

Burkett-Cadena M., Kokalis-Burelle N., Lawrence K.S., VanSanten E. and Kloepper J.W. 2008. Suppressiveness of root-knot nematodes mediated byrhizobacteria. Biol. Control, 47, 5559. doi:10.1016/j.biocontrol.2008.07.008

Eklund E. 1970. Secondary effect of some Pseudomonads in the rhizoplane of peat grown cucumber plants. Suppl. Acta Agric. Scandinavica, 17, 1-57.

El-Hadad M.E., Mustafa M.I., Selim S.M., Mahgoob A.E.A., El-Tayeb T.S. and Abdel Aziz N.H. 2010. In vitro evaluation of some bacterial isolates as biofertilizers and biocontrol agents against the second stage juveniles of Meloidogyne incognita. World J. Microbiol. Biotechnol., 26, 2249-2256. doi: 10.1007/s11274-0100413-8 
Effect of certain Pseudomonas fluorescens isolates on the infection of root-knot nematode, Meloidogyne incognita in tomato and eggplant and the plant growth

El-Nagar H.I., Farahat A.A., Hendy H.H. and El-Hadidy A.A. 1998. The extended effect of Pasteuria penetrans as a biocontrol agent of the root-knot nematodes. Egypt. J. Agronematol., 2, 57-65.

El-Nagdi W.M.A. and Youssef M.M.A. 2015. Nematicidal effect of some aqueous extracts of botanicals and a commercial bacterial byproduct for biocontrolling root knot nematode, Meloidogyne incognita infecting sugar beet. Sci. Agric., 10(2), 55-58.

El-Nagdi W.M.A., Youssef M.M.A., Abd-El-Khair H., Abd-Elgawad M.M.M. and Dawood M.G. 2019. Effectiveness of Bacillus subtilis, B. pumilus, Pseudomonas fluorescens on Meloidogyne incognita infecting cowpea. Pak. J. Nematol., 37(1), 35-43.

El-Sherif M.A., Ali A.H. and Barakat M.I. 1999. Suppressive bacteria associated with plant parasitic nematodes in Egyptian agriculture. Jap. J. Nematol., 24, 55-59.

Gamliel A. and Katan, J. 1993. Suppression of major and minor pathogens by Fluorescent pseudomonads in solarized and non-solarized soil. Phytopathology, 83, 68-75.

Ghini R.F., Patrico R.A., Bettiol W., de Almeida M.G. and Maia N.H.A. 2007. Effect of sewage sludge on suppressiveness to soil-borne plant pathogens. Soil Biol. Biochem., 39, 27972805.

Goszczynska T., Serfontein J.J. and Serfontein S. 2000. Introduction to practical phyto-bacteriology. Sponsored by the Swiss Agency for Development and Cooperation (SDC), Switzerland, $83 \mathrm{p}$.

Kavitha P.G., Jonathan E.I. and SankariMeena K. 2011. Pseudomonas fluorescens for the management of root-knot nematode Meloidogyne incognita in Tomato. Madras Agric. J., 98 (4-6), 176-177.

Lelliot R.A. and Stead D.E. 1987. Methods on Plant Pathology Volume 2, Methods for the Diagnosis of Bacterial Diseases of Plants. British Society for Plant Pathology, Blackwell Scientific Publications, Boston, USA, 216 p.

Mokbel A.A. and Alharbi A.A. 2014. Suppressive effect of some microbial agents on root-knot nematode, Meloidogyne javanica infected eggplant. Aust. J. Crop Sci., 8(10), 1428-1434.

Noweer E.M.A. and Hasabo S.A. 2005. Effect of different Management practices for controlling root-knot nematode Meloidogyne incognita on squash. Egypt. J. Phytopathol., 33, 73-81.
Oka Y., Koltai H., Bar-Eyal M., Mor M., Sharon E., Chet I. and Spiegel Y. 2000. New strategies for the control of plant parasitic nematodes. Pest Manag. Sci., 56, 983-988. doi: 10.1002/15264998(200011)56:11<983::AID-PS233>3.0.CO; $2-X$

Oliveira D.F., Campos V.P., Amaral D.R., Nunes A.S., Pantaleão J.A. and Costa D.A. 2007. Selection of rhizobacteria able to produce metabolites active against Meloidogyne exigua. Europ. J. Plant Pathol., 119, 477-479. doi: 10.1007/s10658-007-9176-y

Schaad N.W. 1980. Laboratory guide for identification of plant pathogenic bacteria.Bacteriology Committee of American Phytopathological society St. Paul, Minnesotia, USA, 72 p.

Sebesta K, Harsksand K. and Vankora J. 1969. Inhibition of de novo RNA synthesis by the insecticidal exotoxin of Bacillus thuringiensis var. Gelechiae. Collect. Gzech. Chem. Communi., 34, 1786-1791.

Snedecor G.W. and Cochran W.G. 1989. Statistical Methods. $8^{\text {th }}$ ed. Ames, lowa: lowa State University Press, USA.

Siddiqui Z.A. and Akhtar M.S. 2009. Effects of antagonistic fungi, plant growth-promoting rhizobacteria and arbuscular mycorrhizal fungi alone and in combination on the reproduction of Meloidogyne incognita and growth of tomato. J. General Plant Pathol., 75, 144-153.

doi:10.1007/s10327-009-0154-4

Singh P. and Siddiqui Z.A. 2010. Biocontrol of root-knot nematode Meloidogyne incognita by the isolates of Bacillus on tomato. Arch. Phytopathol. Plant Protect, 43, 552-561. doi:10.1080/03235400801939904

Sohrabi F., Sheikholeslami M., Heydari R., Rezaee S. and Sharifi R. 2018. Evaluation of four rhizobacteria on tomato growth and suppression of root-knot nematode, Meloidogyne javanica under greenhouse conditions, a pilot study. Egypt. J. Biol. Pest Cont., 28, 1-5.

Stirling G.R. and Sharma R.D. 1990. Attachment of Pasteuria penetrans spores to the root-knot nematode Meloidogyne javanica in soil. Nematologica, 36, 246-252.

Talavera M., Sayadi S., Chirosa-Rios M., Salmerón T., Flor-Peregrin E. and Verdejo-Lucas S. 2012. Perception of the impact of root-knot nematode-induced diseases in horticultural protected crops of south-eastern Spain. Nematology, 14, 517-527. doi: $10.1163 / 156854112 \times 635850$ 
Taylor A.L. and Sasser J.N. 1978. Biology, identification and control of root-knot nematodes (Meloidogyne species). Raleigh (NC): IMP, North Carolina State University Graphics.

Timper P. 2011. Utilization of biological control for managing plant-parasitic nematodes. In: Biological control of plant-parasitic nematodes. Davies K. and Spiegel Y. (Eds.) pp. 259-287. Building coherence between microbial ecology and molecular mechanisms. Dordrecht: Springer.

Trudgill D.L. and Blok V.C. 2001. Apomictic, polyphagous root-knot nematodes: Exceptionally successful and damaging biotrophic root pathogens. Annu. Rev. Phytopathol., 39, 5377.

doi:10.1146/annurev.phyto.39.1.53
Wescott S.W. and Kluepfel D.A. 1993. Inhibition of Criconemellaxenoplaxegg hatch by Pseudomonas aureofaciens. Phytopathology, 83, 12451249.

Young T. W. 1954. An incubation method for collecting migratory- endoparasitic nematodes. Plant Dis. Reptr., 38, 794-795.

Youssef M.M.A., El-Nagdi W.M.A. and Eissa M.F.M. 2014. Population density of root knot nematode, Meloidogyne incognita infecting date palm under stress of aqueous extracts of some botanicals and a commercial bacterial by product. Mid. East J. Appl. Sci., 4(4), 802-805.

Zavaleta Mejia E., Seymour D.V. and Van Gundy S.D. 1989. Effect of the bacterium, Serratia marcescens Bizioon Meloidogyne incognita (Kofoid and White) Chiwood. Rev. Mex. Fitopatol., 7, 178-187. 
تأثير بعض عزلات سيدوموناس فلوبيسنس علي نيماتودا تعقد الجذور ميلويدوجين انكوجنيتاوالنمو الخضري علي نباتي الطماطم والباذنجان

نورا رمضان عبدالعاطي صالح1" - أحمد عيد عبدالمجيد محجوب2 - وفاء محمد عبدالحميد النجدي1 -

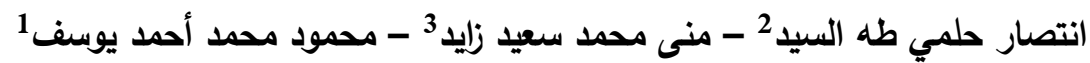

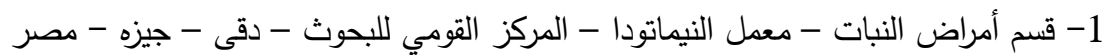

2- قسم وقاية النبات - كلية الزراعة - جامعة عين شمس - ص.ب 68 - حدائق شبرا 11241 - القاهرة - مصر

3- قسم الميكروبيولوجى - كلية الزراعة - جامعة عين شمس - ص.ب 68 - 68 - حدائق شبرا 11241 - 1128 - القاهرة - مصر

*Corresponding author: norasaleh7841@yahoo.com

وعلى الباذنجان سجلت العزلة Pf أعلى نسبة مئوية

لموت اعداد النيماتودا (66.2\%) وكذللك أعلى نسبة

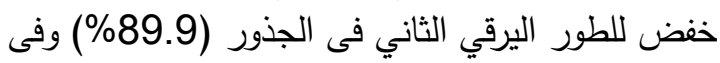

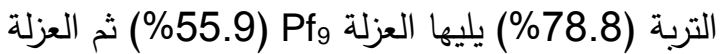
. (554.6) $\mathrm{Pf}_{2}$

Pذ بللك بالنسبة للنمو الخضرى سجلت العزلة

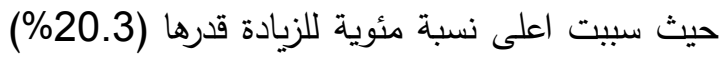

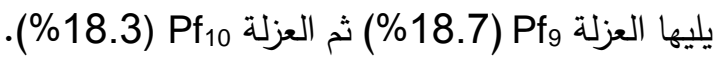
وسجلت العزلة Pf اعلى نسبة زيادة في وزن الجذور

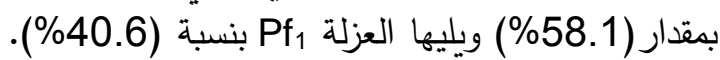

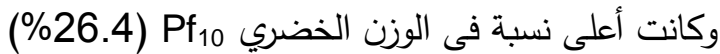

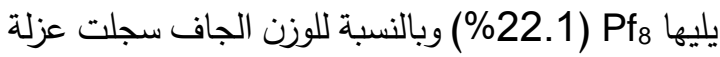
ذب (29.8) Pf ذللك أن السييوموناس فلوربينس فعالة في الة في مكافحة

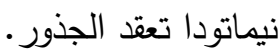

الكلمات المفتاحية: عزلات بكتيريا سيدوموناس الطياس فلوريسنس، الطماطم، الباذنجان، ميلويدوجين انكوجنيتا

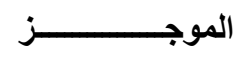

أجريت تجربتان تحت ظروف الصوبه على نباتي الطماطم والباذنجان لتقييم قدرة عزلات بكتريا سيدوموناس تلنات

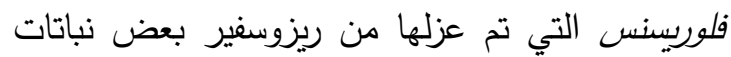
الفصيلة الباذنجانية على القدرة المرضية لنيماتودا تعقد نئد

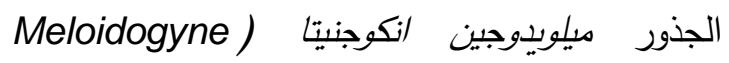
. (incognita

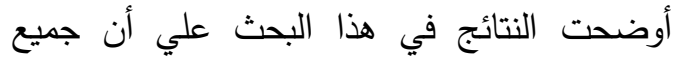

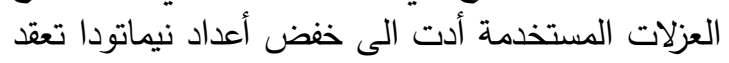

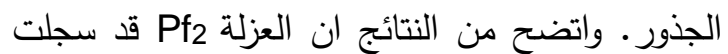
أعلى نسبة مئوية لموت الجداد النئ النيماتودا (61.3\%)

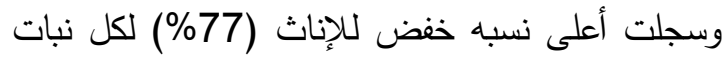

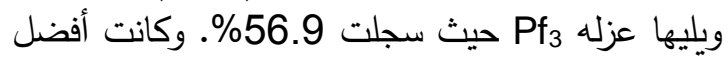

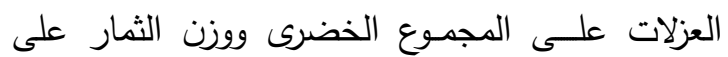

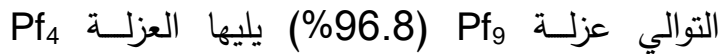

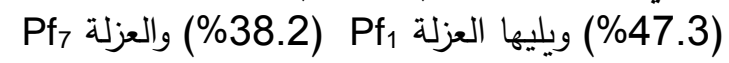
.$(\% 29.8)$ 